\title{
The Occurrence of Coral Species Reported as Threatened in Federally Protected Waters of the US Pacific
}

\author{
Jean Kenyon, ${ }^{1}$ James Maragos, ${ }^{2}$ and Douglas Fenner ${ }^{3}$ \\ ${ }^{1}$ Pacific Islands Fisheries Science Center, NOAA and Joint Institute for Marine and Atmospheric Research, Honolulu, HI 96822, USA \\ ${ }^{2}$ Pacific Reefs National Wildlife Refuge Complex, U.S. Fish and Wildlife Service, Honolulu, HI 96850-5231, USA \\ ${ }^{3}$ Department of Marine and Wildlife Resources, American Samoa Government Pago Pago, AS 96799, USA
}

Correspondence should be addressed to Jean Kenyon, jkenyon@hawaii.edu

Received 15 June 2010; Accepted 3 September 2010

Academic Editor: Robert J. Toonen

Copyright () 2011 Jean Kenyon et al. This is an open access article distributed under the Creative Commons Attribution License, which permits unrestricted use, distribution, and reproduction in any medium, provided the original work is properly cited.

\begin{abstract}
A recent study reported that seventy-five species of reef-building corals, considered to be at elevated extinction risk when assessed by the criteria of the International Union for Conservation of Nature, occur in Pacific waters under United States jurisdiction. Closer examination substantiates records of occurrence for 66 species, while records for the other 9 species were based on misinterpretations or are otherwise uncertain. Of these, at least 55 have been reported from reef habitat under federal protection within National Parks, Marine National Monuments, National Marine Sanctuaries, and National Wildlife Refuges. The highest number of species (31) is found within the Ofu Island unit of the National Park of American Samoa, followed by Kingman Reef (24) and Palmyra Atoll (21), both within the Pacific Remote Islands Marine National Monument. Federally protected areas already in place serve as important habitats for resources whose stewardship needs and priorities may vary over time.
\end{abstract}

\section{Introduction}

The International Union for Conservation of Nature (IUCN) Red List of Threatened Species is a tool that is widely used for focusing attention on species of potential conservation concern $[1,2]$. Assessments based on the IUCN Red List Criteria allocate species to categories of extinction risk using quantitative rules based on population sizes and decline rates, and range areas and declines. Categories range from "Least Concern" with very little probability of extinction to high risk "Critically Endangered". Three categories collectively considered "threatened" and representing increasing extinction risk (Vulnerable, Endangered, and Critically Endangered) are intended to serve as one means of setting priority measures for biodiversity conservation [3].

Corals and coral reefs in many regions of the world are reported to be in a state of decline due to numerous local and global anthropogenic stressors including coastal point source pollution, agricultural and land use practices, overutilization for commercial or recreational purposes, and climate change and ocean acidification [4-9]. In response to their declining condition, three workshops were conducted in 2006 and
2007 to apply the IUCN Red List Categories and Criteria [10] in assessing the extinction risk of all known zooxanthellate reef-building corals from the order Scleractinia plus reefbuilding octocorals and hydrocorals (families Helioporidae, Tubiporidae, and Milleporidae). Of the 704 species for which there were sufficient data to assign a category, 231 species $(32.8 \%)$ were assigned to one of the three categories considered threatened [3]. Of these, 75 species were reported to occur in Pacific waters under US jurisdiction (Hawai $i$, American Samoa, Guam, Northern Mariana Islands, Wake Atoll, Johnston Atoll, Howland Island, Baker Island, Jarvis Island, Palmyra Atoll, and Kingman Reef).

Throughout the US Pacific, substantial areas of coral reef habitat are under federal protection within the boundaries of National Wildlife Refuges, Marine National Monuments, National Marine Sanctuaries, or National Parks (Table 1). While the establishment of protected areas may be driven by one or several key resources (e.g., the safeguarding of breeding and calving habitat for the endangered humpback whale by the Hawaiian Humpback Whale National Marine Sanctuary), their legal mandate includes the comprehensive management of the ecological, historical, and aesthetic 
Table 1: Marine National Monuments, National Marine Sanctuaries, National Wildlife Refuges, and National Parks with coral reef habitat in the US Pacific.

\begin{tabular}{|c|c|c|}
\hline & General Location & Units \\
\hline \multicolumn{3}{|l|}{ Marine National Monuments } \\
\hline Papahānaumokuākea (PMNM) & $\begin{array}{l}\text { Northwestern Hawaiian } \\
\text { Islands }\end{array}$ & $\begin{array}{l}\text { Nihoa*, Necker*, French Frigate Shoals*, } \\
\text { Gardner*, Maro*, Laysan*, Lisianski*, } \\
\text { Pearl and Hermes*, Midway NWR, Kure }\end{array}$ \\
\hline Pacific Remote Islands (PRIMNM) & Central Pacific & $\begin{array}{l}\text { Johnston Atoll NWR, Howland Island } \\
\text { NWR, Baker Island NWR, Jarvis Island } \\
\text { NWR, Palmyra Atoll NWR, Kingman } \\
\text { Reef NWR, Wake Atoll NWR. }\end{array}$ \\
\hline Rose Atoll (RAMNM) & American Samoa & Rose Atoll NWR \\
\hline $\begin{array}{l}\text { Marianas Trench, Islands Unit } \\
(\text { MTMNM) }\end{array}$ & Northern Mariana Islands & Asuncion, Maug, Farallon de Pajaros \\
\hline \multicolumn{3}{|l|}{ National Marine Sanctuaries } \\
\hline $\begin{array}{l}\text { Hawaiian Islands Humpback Whale } \\
\text { (HIHWNMS) }\end{array}$ & Main Hawaiian Islands & $\begin{array}{l}\text { Maui, Lana'i, Moloka'i, O’ahu, Kaua'i, } \\
\text { Hawai'i }\end{array}$ \\
\hline Fagatele Bay (FBNMS) & American Samoa & Tutuila \\
\hline \multicolumn{3}{|l|}{ National Parks } \\
\hline NP of American Samoa (NPSA) & American Samoa & Tutuila, Ofu-Olosega, Ta’u \\
\hline War in the Pacific NHP (WAPA) & Southern Mariana Islands & Guam \\
\hline American Memorial Park (AMME) & Northern Mariana Islands & Saipan \\
\hline Kalaupapa NHP (KALA) & Main Hawaiian Islands & Moloka i \\
\hline Haleakalā NP (HALE) & Main Hawaiian Islands & Maui \\
\hline Pu'ukoholā Heiau NHS (PUHE) & Main Hawaiian Islands & Hawai'i \\
\hline Kaloko-Honokōhau NHP (KAHO) & Main Hawaiian Islands & Hawai' $\mathrm{i}$ \\
\hline Pu'uhonua o Hōnaunau NHP & Main Hawaiian Islands & Hawai'i \\
\hline $\begin{array}{l}(\text { PUHO }) \\
\text { Hawai'i Volcanoes NP (HAVO) }\end{array}$ & Main Hawaiian Islands & Hawai'i \\
\hline Other National Wildlife Refuges & Ritidian Point & Guam \\
\hline
\end{tabular}

A "unit" is here considered to be a geographically distinct island, atoll, or reef system. NWR: National Wildlife Refuge, *: unit within Hawaiian Islands NWR.

resources within them. As physical and biological resources continue to respond to environmental change driven by human enterprise, protected areas may provide an umbrella of shelter to habitats and communities not originally envisioned in need of refuge. However, some threats such as climate change are very widespread and challenge the ability of protected areas to limit their effects.

The purpose of this paper is to explore the currently known occurrence within federally protected waters of the 75 coral species assessed as threatened by the IUCN and reported by that body to occur within the US Pacific. The number of alleged threatened species occurring in each system of federal protection is reported and those species that are not presently known to occur within the boundaries of US federal protection are identified.

\section{Materials and Methods}

Assessments based on the IUCN Red List criteria were obtained from Carpenter et al. [3] Supporting Online Material. Peer-reviewed literature, published and unpublished reports, monitoring program databases, and local experts were consulted (Table 2) to corroborate the occurrence of the 75 species stated to occur within US Pacific waters by Carpenter et al. [3] and the IUCN Red List database [43]. Occurrences within the boundaries of federally protected waters were determined from a subset of this suite of sources. No data were available for Haleakalā National Park, Hawai'i Volcanoes National Park, or American Memorial Park (Brown, pers. comm.).

\section{Results}

Of the 75 coral species stated to occur in the US Pacific in Carpenter et al. [3] and the IUCN database [43], substantiated records could be identified for 66 species. Six species (Acanthastrea regularis, Acropora tenella, Anacropora puertogalerae, Anacropora spinosa, Pectinia alcicornis, and Physogyra lichtensteini) are shown on distribution maps in Veron [33] as occurring in the Mariana Archipelago, which is the basis of their records in US waters in the IUCN database. However, these records were based on photos submitted to Veron by G. Paulay from Palau and elsewhere that were mistakenly attributed to Guam [31], (G. Paulay pers. comm. Veron pers. comm.), and these 6 species have not been authenticated by other reports from US waters. A seventh 
TABle 2: Data sources used to substantiate the occurrence of 75 IUCN Red List coral species in the US Pacific and in federally protected areas.

\begin{tabular}{ll}
\hline Location & References \\
\hline \multirow{2}{*}{ Hawai'i } & {$[11-25]$} \\
& NPS Pacific Islands Network monitoring database \\
& NOAA Pacific Islands Fisheries Science Center (PIFSC) Coral Reef Ecosystem \\
& Division (CRED) database \\
& {$[26,27]$} \\
Pacific Remote Islands & Maragos unpubl. data 2000-2010 \\
& Kenyon and Bonito unpubl. data 2005 \\
Rose Atoll & {$[28]$} \\
& Fenner unpubl. data 2010 \\
& {$[29-33]$} \\
Marianas Archipelago & D. Burdick unpubl. data 2010 \\
& NOAA PIFSC CRED database \\
& G. Paulay, pers. comm. \\
& {$[30,34-42]$} \\
American Samoa & Birkeland unpubl. data 1979-2007 \\
& Fenner unpubl. data 2010 \\
\hline
\end{tabular}

species (Acropora lokani) was identified from photographs compared to Veron [33] but was reidentified as A. caroliniana based on the original description of $A$. lokani in Wallace [44] and the description of A. caroliniana in Wallace [30] (Fenner, pers. comm.). For 2 additional species (Acropora dendrum and Caulastrea echinulata), the initial tentative identifications from photographs are now uncertain (Fenner, pers. comm.).

Of these 66 species, records of occurrence in federally protected waters were identified for 55 species. Forty-three species were recorded within National Parks (NP), 39 species within Marine National Monuments (MNM) and National Wildlife Refuges within the MNM, and 18 within National Marine Sanctuaries (NMS) (Table 3, where data are reported as the number of discrete islands or atolls ("units") where each species has been recorded. Additionally, a supplementary online table incorporates data presented in Tables 3, 4 and 5 in a single matrix.) The most frequently occurring species, reported at 10 or more of the 26 major units afforded federal protection from which data have been reported (excluding the Hawaiian Islands Humpback Whale NMS where reported occurrence data were not attributed to the 6 component islands), were Montipora patula (15), Cyphastrea ocellina (13), Montipora flabellata (13), Psammocora stellata (13), Pocillopora elegans (12), Leptoseris incrustans (10), Montipora caliculata (10), and Pocillopora danae (10). Twenty species were recorded from 3 to 8 reef units, and 27 species were recorded at only 1 or 2 reef units.

Eleven of the 66 species with substantiated records of occurrence in the US Pacific have not been recorded within federally protected waters (Table 3 ). Of these, 5 species (Acanthastrea hemprichii, Acanthastrea ishigakiensis, Acropora jacquelineae, Acropora pharaonis, and Euphyllia paradivisa) have been reported from single locations at
Tutuila, American Samoa, and were rare, represented by only 1 or 2 colonies (Fenner, pers. comm.). Pachyseris rugosa and Turbinaria peltata have been reported at several locations by several authors in American Samoa [36, 37, 40], (Birkeland unpubl. data, Fenner unpubl. data), indicating that they are relatively more abundant. Four species (Alveopora fenestrata, Euphyllia paraancora, Millepora foveolata, and Seriatopora aculeata) have been reported from Guam [34], (D. Burdick unpubl. data) though abundance data are not available. The occurrence of P. rugosa in the Mariana Archipelago as shown in Veron [33] has not been substantiated by other sources and is based on the misattribution of photographs as indicated previously for 6 other species (Veron pers. comm.).

Of the 39 species recorded within the Marine National Monuments and National Wildlife Refuges (NWR) (Table 4), the highest numbers of Red List threatened coral species have been recorded from Kingman Reef NWR (24) and Palmyra Atoll NWR (21) in the Pacific Remote Islands MNM followed by Rose Atoll NWR and MNM (17). In the Islands Unit of the Mariana Trench MNM, the highest number of Red List threatened coral species has been recorded at Asuncion Island (7). In the Papahānaumokuākea MNM covering the Northwestern Hawaiian Islands, the highest numbers of Red List threatened coral species (5) have been recorded at French Frigate Shoals, Maro Reef, Pearl and Hermes Atoll, and Midway Atoll.

Of all the federally protected locations, the highest number of Red List threatened coral species (31) has been recorded from Ofu Island in the National Park of American Samoa (Table 5). Fagatele Bay NMS and the Tutuila section of the National Park of American Samoa each host 12 Red List threatened coral species, despite the substantially smaller size of Fagatele Bay $\left(0.65 \mathrm{~km}^{2}\right.$ and $4.9 \mathrm{~km}^{2}$, resp. $)[45,46]$. In Guam, War in the Pacific National Historical Park hosted 
TAble 3: IUCN Red List Categories for 66 species with substantiated records of occurrence in the US Pacific, ranked by number of units (geographically distinct islands, atolls, or reef systems) where found within federally protected waters.

\begin{tabular}{|c|c|c|c|c|c|}
\hline & $\begin{array}{l}\text { IUCN Red List } \\
\text { Category }\end{array}$ & National Parks & $\begin{array}{l}\text { Marine National } \\
\text { Monuments }\end{array}$ & $\begin{array}{c}\text { National Marine } \\
\text { Sanctuaries }\end{array}$ & Total units \\
\hline Montipora patula & VU & 2 & 13 & 1 & 15 \\
\hline Cyphastrea ocellina & VU & 2 & 11 & 1 & 13 \\
\hline Montipora flabellata & VU & 1 & 12 & 1 & 13 \\
\hline Psammocora stellata & VU & 0 & 13 & 1 & 13 \\
\hline Pocillopora elegans & VU & 1 & 11 & 1 & 12 \\
\hline Montipora caliculata & VU & 2 & 7 & 1 & 10 \\
\hline Pocillopora danae & VU & 2 & 8 & 0 & 10 \\
\hline Leptoseris incrustans & VU & 2 & 7 & 1 & 10 \\
\hline Acropora verweyi & $\mathrm{VU}$ & 2 & 6 & 0 & 8 \\
\hline Acropora acuminata & $\mathrm{VU}$ & 1 & 5 & 1 & 7 \\
\hline Acropora paniculata & VU & 1 & 5 & 0 & 6 \\
\hline Turbinaria reniformis & VU & 1 & 4 & 1 & 6 \\
\hline Acropora aspera & VU & 2 & 3 & 0 & 5 \\
\hline Acropora retusa & VU & 1 & 4 & 0 & 5 \\
\hline Acropora vaughani & VU & 1 & 4 & 0 & 5 \\
\hline Pavona venosa & $\mathrm{VU}$ & 3 & 2 & 1 & 5 \\
\hline Turbinaria stellulata & VU & 1 & 4 & 0 & 5 \\
\hline Acropora aculeus & VU & 1 & 3 & 0 & 4 \\
\hline Acropora globiceps & VU & 1 & 3 & 0 & 4 \\
\hline Acropora microclados & VU & 1 & 3 & 0 & 4 \\
\hline Acropora polystoma & VU & 1 & 3 & 0 & 4 \\
\hline Cyphastrea agassizi & VU & 2 & 2 & 1 & 4 \\
\hline Heliopora coerulea & VU & 2 & 2 & 0 & 4 \\
\hline Acropora palmerae & $\mathrm{VU}$ & 1 & 1 & 1 & 3 \\
\hline Alveopora verrilliana & VU & 0 & 3 & 0 & 3 \\
\hline Isopora cuneata & VU & 1 & 2 & 0 & 3 \\
\hline Montipora dilatata & EN & 0 & 3 & 0 & 3 \\
\hline Montipora lobulata & VU & 0 & 2 & 1 & 3 \\
\hline Acropora striata & VU & 1 & 1 & 0 & 2 \\
\hline Astreopora cucullata & VU & 1 & 1 & 0 & 2 \\
\hline Isopora crateriformis & VU & 2 & 0 & 1 & 2 \\
\hline Leptoseris yabei & VU & 1 & 1 & 0 & 2 \\
\hline Millepora tuberosa & $\mathrm{EN}$ & 2 & 0 & 1 & 2 \\
\hline Montipora calcarea & VU & 1 & 1 & 1 & 2 \\
\hline Pavona cactus & VU & 1 & 1 & 0 & 2 \\
\hline Pavona decussata & VU & 2 & 0 & 0 & 2 \\
\hline Acanthastrea brevis & VU & 0 & 1 & 0 & 1 \\
\hline Acropora donei & VU & 1 & 0 & 0 & 1 \\
\hline Acropora horrida & $\mathrm{VU}$ & 1 & 0 & 0 & 1 \\
\hline Acropora listeri & VU & 1 & 0 & 0 & 1 \\
\hline Acropora rudis & EN & 0 & 0 & 1 & 1 \\
\hline Acropora speciosa & VU & 0 & 1 & 0 & 1 \\
\hline Alveopora allingi & VU & 1 & 0 & 0 & 1 \\
\hline Barabattoia laddi & $\mathrm{VU}$ & 0 & 1 & 0 & 1 \\
\hline Euphyllia cristata & $\mathrm{VU}$ & 1 & 0 & 0 & 1 \\
\hline Galaxea astreata & VU & 1 & 0 & 0 & 1 \\
\hline Montipora angulata & VU & 0 & 1 & 0 & 1 \\
\hline
\end{tabular}


Table 3: Continued.

\begin{tabular}{|c|c|c|c|c|c|}
\hline & $\begin{array}{l}\text { IUCN Red List } \\
\text { Category }\end{array}$ & National Parks & $\begin{array}{l}\text { Marine National } \\
\text { Monuments }\end{array}$ & $\begin{array}{l}\text { National Marine } \\
\text { Sanctuaries }\end{array}$ & Total units \\
\hline $\begin{array}{l}\text { Montipora } \\
\text { australiensis }\end{array}$ & $\mathrm{VU}$ & 1 & 0 & 0 & 1 \\
\hline Pavona bipartita & $\mathrm{VU}$ & 0 & 1 & 0 & 1 \\
\hline Pavona diffluens & $\mathrm{VU}$ & 1 & 0 & 0 & 1 \\
\hline Porites horizontalata & VU & 1 & 0 & 0 & 1 \\
\hline Porites napopora & VU & 0 & 0 & 1 & 1 \\
\hline Porites nigrescens & VU & 1 & 0 & 0 & 1 \\
\hline Porites pukoensis & $\mathrm{CR}$ & 0 & 1 & 0 & 1 \\
\hline $\begin{array}{l}\text { Turbinaria } \\
\text { mesenterina }\end{array}$ & $\mathrm{VU}$ & 1 & 0 & 0 & 1 \\
\hline $\begin{array}{l}\text { Acanthastrea } \\
\text { hemprichii }\end{array}$ & $\mathrm{VU}$ & 0 & 0 & 0 & 0 \\
\hline $\begin{array}{l}\text { Acanthastrea } \\
\text { ishigakiensis }\end{array}$ & $\mathrm{VU}$ & 0 & 0 & 0 & 0 \\
\hline Acropora jacquelineae & VU & 0 & 0 & 0 & 0 \\
\hline Acropora pharaonis & $\mathrm{VU}$ & 0 & 0 & 0 & 0 \\
\hline Alveopora fenestrata & $\mathrm{VU}$ & 0 & 0 & 0 & 0 \\
\hline Euphyllia paraancora & VU & 0 & 0 & 0 & 0 \\
\hline Euphyllia paradivisa & VU & 0 & 0 & 0 & 0 \\
\hline Millepora foveolata & VU & 0 & 0 & 0 & 0 \\
\hline Pachyseris rugosa & $\mathrm{VU}$ & 0 & 0 & 0 & 0 \\
\hline Seriatopora aculeata & VU & 0 & 0 & 0 & 0 \\
\hline Turbinaria peltata & VU & 0 & 0 & 0 & 0 \\
\hline
\end{tabular}

"Total units" is not strictly additive, as Tutuila hosts both a National Park and a National Marine Sanctuary.

6 Red List threatened coral species. In Hawai' $i$, the highest number of Red List threatened coral species (5) was recorded in the Hawaiian Islands Humpback Whale NMS.

\section{Discussion}

This paper summarizes information drawn from publications, reports, museum voucher specimens, monitoring program databases, and coral expert records to the extent that species occurrence could be assigned to benthic habitat within the boundaries of federally protected waters of the US Pacific. However, not all sources provide detailed geographic information; see for example, [32], and not all benthic habitat within the boundaries of federal protection has been surveyed and assessed. Consequently, the extent to which IUCN Red List threatened coral species appear to occur within Marine National Monuments, National Wildlife Refuges, National Parks, and National Marine Sanctuaries of the US Pacific is likely underestimated.

Occurrence records are also likely confounded by problems inherent to current methods of species identification and to classifying corals solely on the basis of morphological criteria. Only relatively recently has coral taxonomy reached a sufficiently comprehensive stage to enable identification of many species over wide areas; see for example, [31, 33, 47]. Corals are highly variable at all scales, and many taxonomic problems remain. A generally accepted hierarchy of data quality, from highest to lowest, is species identification based on examination of voucher specimens, primarily skeletal remains; examination of photographs of both skeletons and living corals; visual field inspection. Even identification of voucher specimens requires resources that are often not available, such as the original description and the type specimen. Nevertheless, many publications and reports are based on visual field identification which for some taxa can be challenging even for veteran experts. In this study, though Pocillopora elegans and $P$. danae are considered valid species [33], they can be difficult to distinguish from P. meandrina and $P$. verrucosa, respectively, in the field where they cooccur, and consequently their representation within federally protected waters in the current analysis may be over- or underestimated. Similarly, Porites pukoensis, described from Vaughan [48] and said to be restricted to a single small site off the coast of Moloka 'i Island in Hawail $i$ [3, 49], has been reported from Kingman Reef NWR in the Pacific Remote Islands Marine National Monument (Table 4) based on visual identification by a coral taxonomist (Maragos, unpubl. data 2010). Porites pukoensis has also been reported from American Samoa [34, 35], Indonesia [50], Tabuaeran Atoll in the Line Islands and Kanton Atoll in the Phoenix Islands [51, 52], Madagascar [53, 54], Mauritius [54], and Reunion $[53,54]$, demonstrating the difficulty of validating 


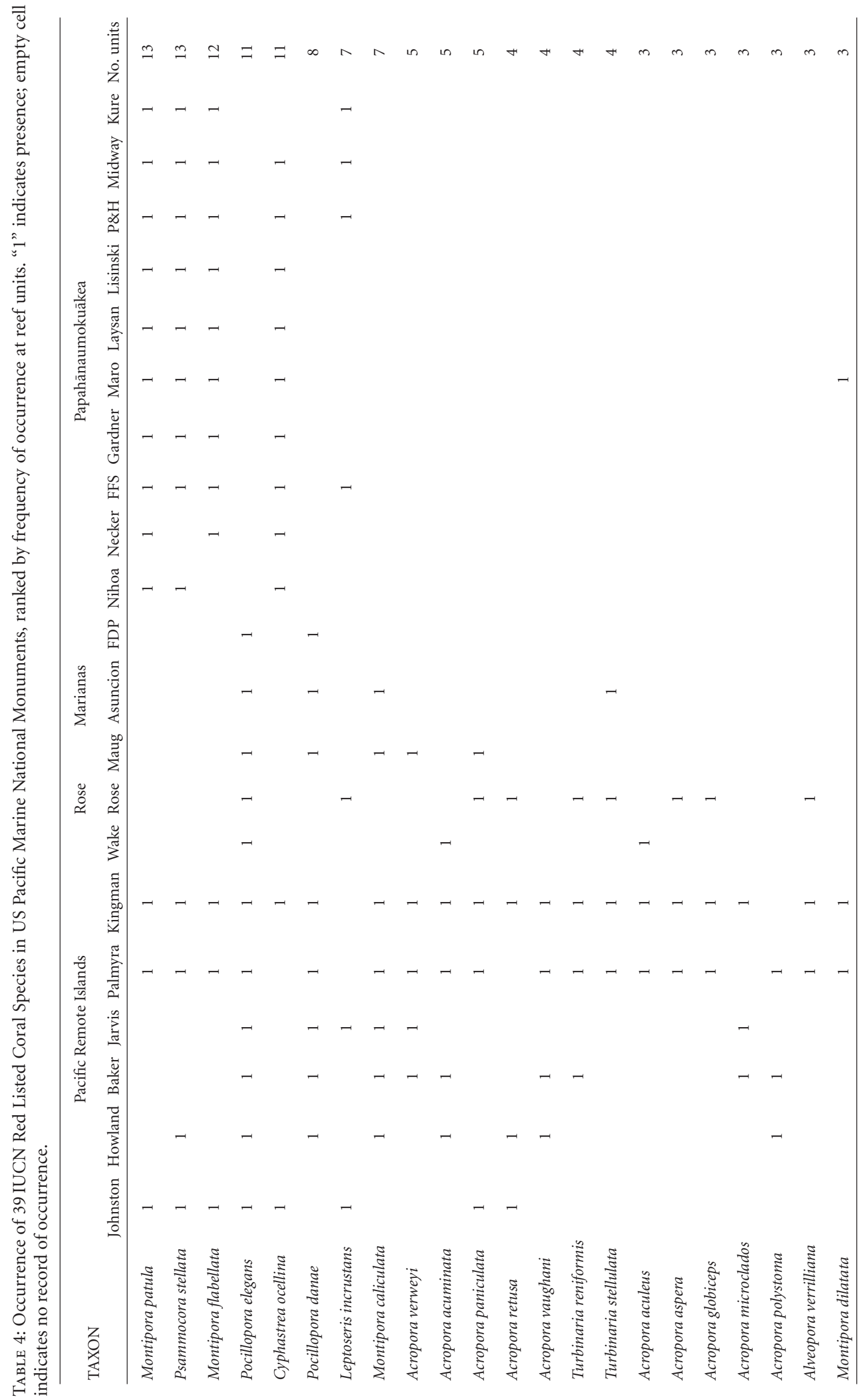




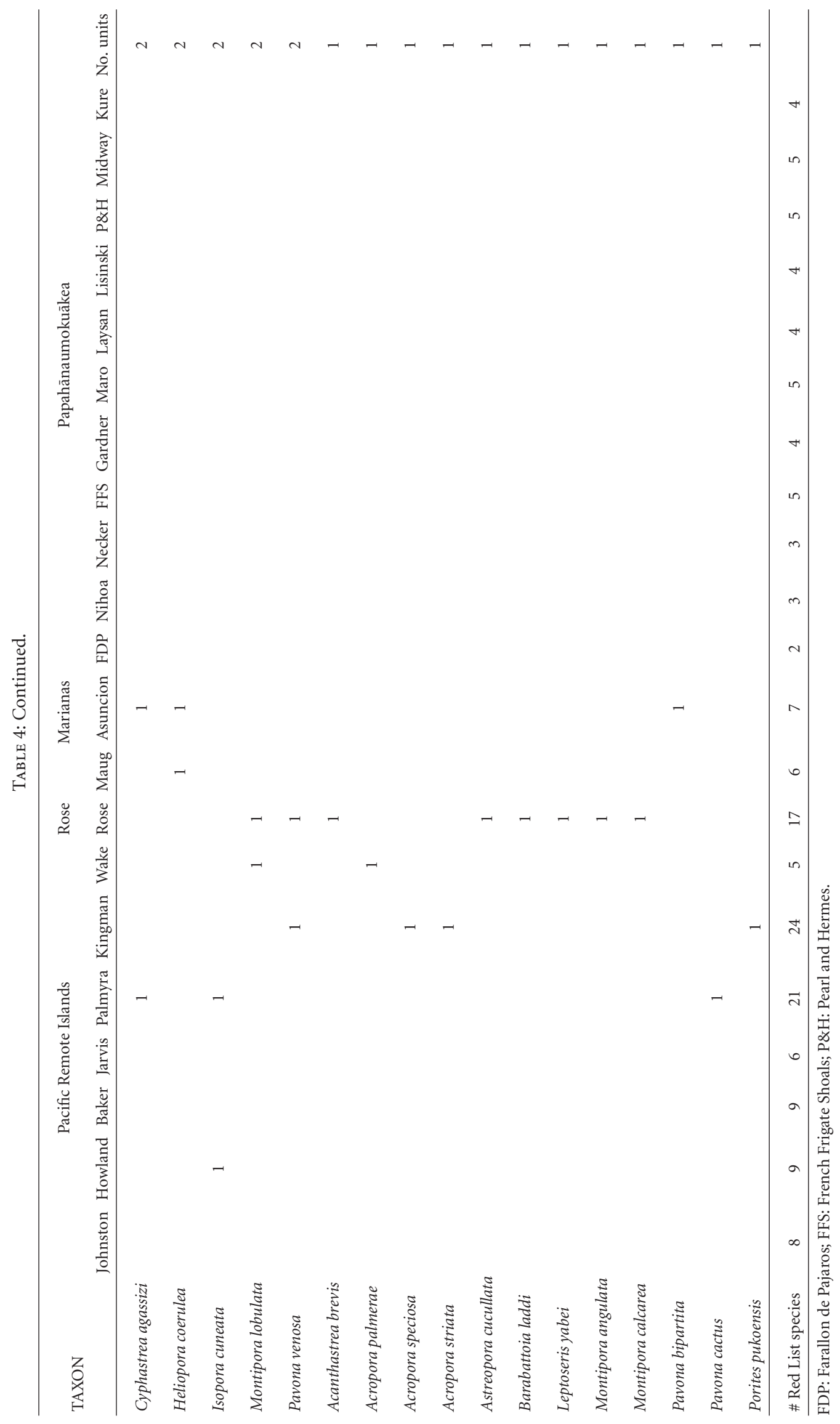




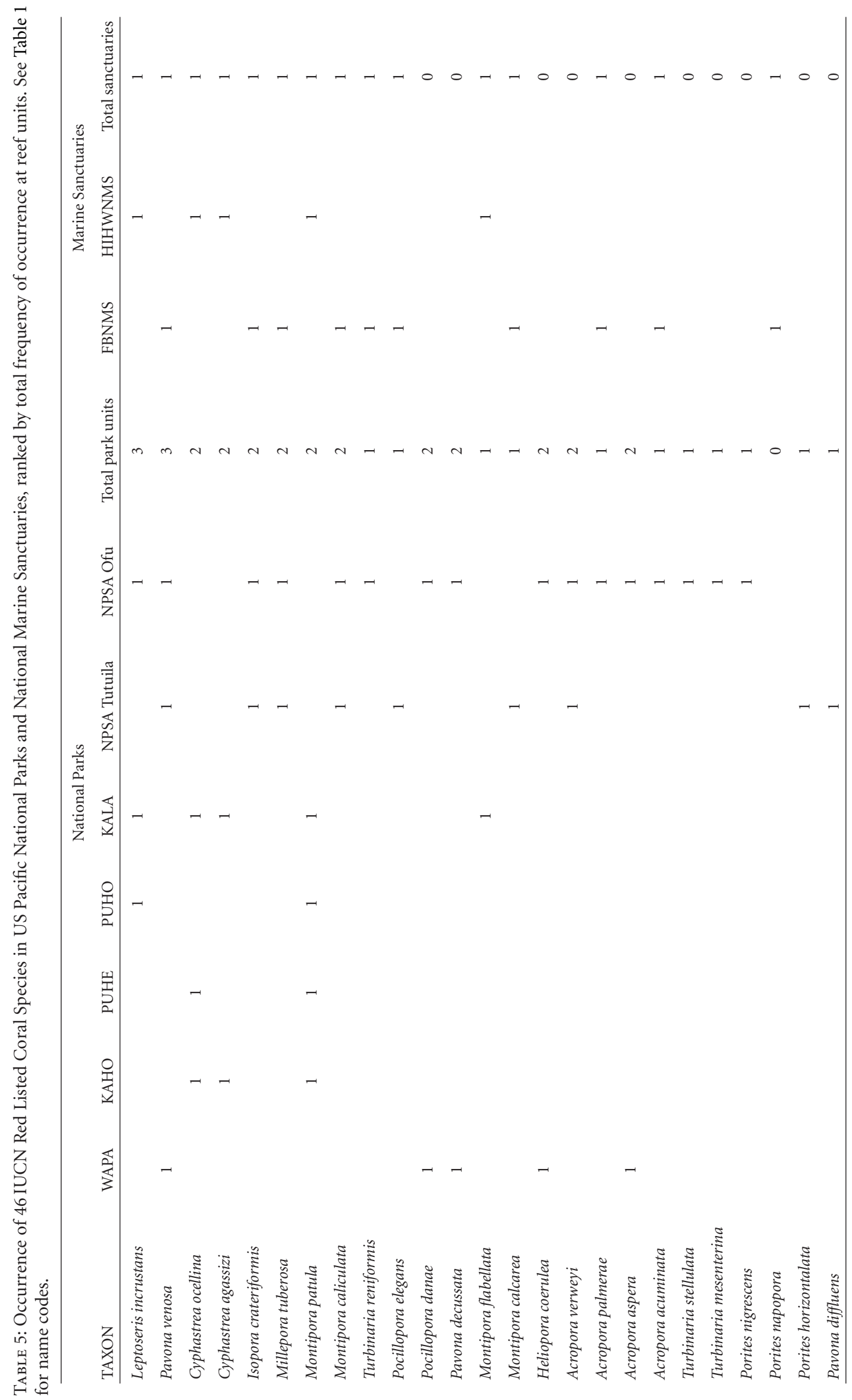




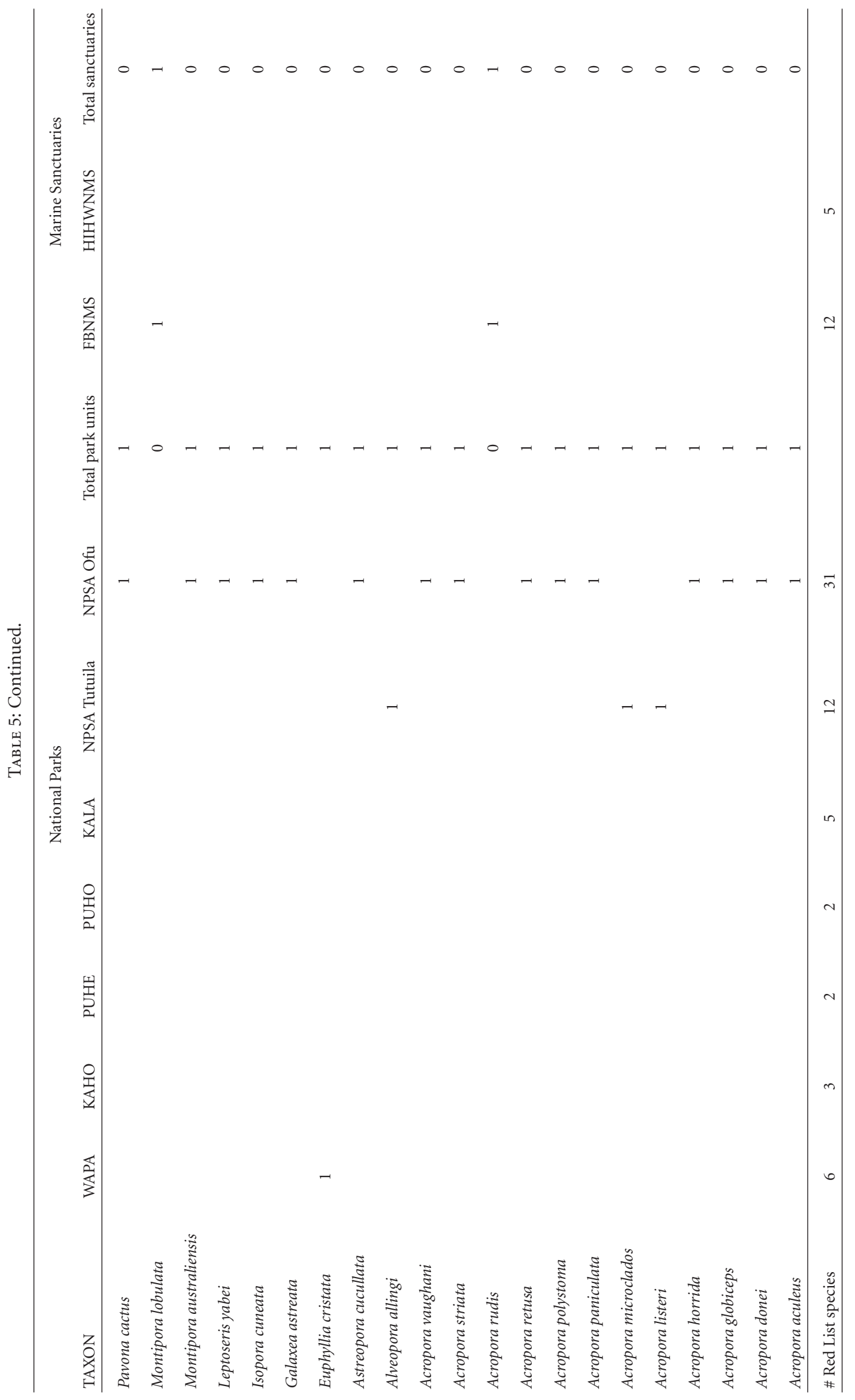


species distributions even from peer-reviewed publications as the data quality underlying the classification is frequently not stated, and samples that can be used for later verification are rarely collected. Moreover, this species is similar to another species reported from Australia (Porites stephensoni), and molecular analysis may be needed to determine whether these are the same or different species. Montipora dilatata is considered a valid species based on morphological criteria $[14,33,48,55]$ and is thought to have a restricted and disjunct distribution in the Hawaiian Archipelago [3, 13, 14, 33, 56]; however, it has also been reported from Palmyra Atoll NWR [26] and Kingman Reef NWR (Maragos unpubl. data). Moreover, examination of a suite of molecular markers (mitochondrial and nuclear) in addition to a suite of measurements on skeletal microstructure suggest that Montipora dilatata, M. flabellata, and M. cf. turgescens reported from Hawai' $i$ may be morphological variants of the same biological species [57]. However, Montipora turgescens at its type locality in Australia may not be the same as those identified from Hawai'i by Veron [33], which are separated by a distance of more than $5000 \mathrm{~km}$, and as a result, the latter may still be a valid species. Occurrence records in this study are based on peer-reviewed literature and the reported observations of scientists widely considered as experts in their field, and therefore, they represent the most current reliable application of coral species identification.

Of the 75 petitioned Pacific species, all but four (Montipora dilatata, M. flabellata, M. patula, and Porites pukoensis) were evaluated under IUCN Red List subcriterion A4, an observed, estimated, inferred, projected, or suspected population size reduction of $\geq 50 \%$ (for Endangered, EN) or $30 \%$ (for Vulnerable, VU) over two generations in the past and one into the future, where the generation length for all but 2 species was considered as 10 years [3]. Speciesspecific population trend data were not available for the Pacific coral species across their global distributional range, so loss of coral cover within a species distribution in combination with life history traits were used as a surrogate for population reduction. For each species, a quantitative estimate of population reduction was calculated using the coral reef area within its distributional range in conjunction with an estimate of the percent of total coral cover loss or the combined percent of total coral cover loss and critically declining reef [3]. "Total coral cover loss" was operationally defined as the percentage of reef with $>90 \%$ coral cover loss over at least the past 15 to 20 years, and "critically declining reef" was operationally defined as the percentage of reefs with $50 \%-90 \%$ coral cover loss and likely to join the total coral cover loss category within 10 to 20 years [6]. Three species (Montipora flabellata, M. patula, and Porites pukoensis) were evaluated under IUCN Red List Criterion $\mathrm{D}$, which can be applied to very small populations, where "population" is defined as the total number of individuals of the taxon [10]. Porites pukoensis was listed as Critically Endangered as the population size was estimated to number fewer than 50 mature individuals. Montipora flabellata and M. patula were listed as Vulnerable because they are endemic to Hawai' $i$ and the number of locations for these species was less than five, where "location" is defined as "a geographically or ecologically distinct area in which a single threatening event can rapidly affect all individuals of the taxon present". Montipora dilatata was evaluated under IUCN Red List Criterion B, which can be applied to very geographically restricted populations, and was listed as Endangered as its area of occupancy was less than $500 \mathrm{~km}^{2}$ and it existed in less than 5 locations.

While widely viewed as a useful index in estimating extinction risk, the IUCN Red List of Threatened Species carries no weight of law. In October 2009 the nongovernmental organization Center for Biological Diversity petitioned the NOAA to list 83 species of corals under the US Endangered Species Act, including the 75 Pacific species addressed in this study. The Endangered Species Act does have the weight of law. As of this publication, the NMFS is currently leading the process to independently evaluate the extinction risk of these species, and if listed as endangered species, these corals would receive legal protection. Coral reef habitat presently under federal protection harbors at least 55 of the 66 species with validated occurrence records in the US, with three reef units-Palmyra Atoll NWR, Kingman Reef NWR, and the Ofu unit of the National Park of American Samoa-each hosting more than 20 Red List threatened coral species. Protected areas already in place serve as important habitats and may be models for other areas deserving protection because they harbor species at elevated risk.

\section{Acknowledgments}

The authors thank the officers and crew of the NOAA Ship Hi'ialakai for logistical assistance in conducting dedicated surveys throughout American Samoa and the Pacific Remote Islands Marine National Monument. Eric Brown shared data from the National Park Service Pacific Island Monitoring Network database.

\section{References}

[1] U. Gärdenfors, C. Hilton-Taylor, G. M. Mace, and J. P. Rodríguez, "The application of IUCN Red List criteria at regional levels," Conservation Biology, vol. 15, no. 5, pp. 12061212, 2001.

[2] A. S. L. Rodrigues, J. D. Pilgrim, J. F. Lamoreux, M. Hoffmann, and T. M. Brooks, "The value of the IUCN Red List for conservation," Trends in Ecology and Evolution, vol. 21, no. 2, pp. 71-76, 2006.

[3] K. E. Carpenter, M. Abrar, G. Aeby et al., "One-third of reef-building corals face elevated extinction risk from climate change and local impacts," Science, vol. 321, no. 5888, pp. 560$563,2008$.

[4] G. Hodgson, "A global assessment of human effects on coral reefs," Marine Pollution Bulletin, vol. 38, no. 5, pp. 345-355, 1999.

[5] T. A. Gardner, I. M. Côté, J. A. Gill, A. Grant, and A. R. Watkinson, "Long-term region-wide declines in Caribbean corals," Science, vol. 301, no. 5635, pp. 958-960, 2003.

[6] C. Wilkinson, Status of Coral Reefs of the World, Australian Institute of Marine Science, Townsville, Australia, 2004. 
[7] J. M. Pandolfi, J. B. C. Jackson, N. Baron et al., "Are U.S. coral reefs on the slippery slope to slime?" Science, vol. 307, no. 5716, pp. 1725-1726, 2005.

[8] J. F. Bruno and E. R. Selig, "Regional decline of coral cover in the Indo-Pacific: timing, extent, and subregional comparisons," PLoS ONE, vol. 2, no. 8, article e711, 2007.

[9] J. E. N. Veron, O. Hoegh-Guldberg, T. M. Lenton et al., "The coral reef crisis: the critical importance of $<350 \mathrm{ppm} \mathrm{CO}_{2}$," Marine Pollution Bulletin, vol. 58, no. 10, pp. 1428-1436, 2009.

[10] IUCN Red List Categories and Criteria: Version 3.1., 2001, http: / /www.iucnredlist.org/technical-documents/ categoriesand-criteria.

[11] J. D. Parrish, G. D. Smith, and J. E. Norris, "Resources of the marine waters of Kaloko-Honokohau National Historical Park," Tech. Rep. 74, Cooperative National Park Resources Study Unit, 1990.

[12] K. Aki, R. Brock, J. Miller et al., "A site characterization study for the Hawaiian Islands Humpback Whale National Marine Sanctuary," Tech. Rep. 94-06, University of Hawai' i Sea Grant, 1994.

[13] J. E. Maragos, D. C. Potts, G. Aeby et al., "2000-2002 Rapid Ecological Assessment of Corals (Anthozoa) on shallow reefs of the Northwestern Hawaiian Islands. Part 1: species and distribution," Pacific Science, vol. 58, no. 2, pp. 211-230, 2004.

[14] D. Fenner, Corals of Hawai ' $i$, Mutual, Honolulu, Hawai' $i$, USA, 2005.

[15] S. Godwin and H. Bollick, "Inventory of intertidal and shallow subtidal marine invertebrates at Kalaupapa National Historical Park," Tech. Rep. 2006-003, Pacific Cooperative Studies Unit, 2006.

[16] S. E. Kahng and J. E. Maragos, "The deepest, zooxanthellate scleractinian corals in the world?" Coral Reefs, vol. 25, no. 2, p. 254, 2006.

[17] J. C. Kenyon, P. S. Vroom, K. N. Page, M. J. Dunlap, C. B. Wilkinson, and G. S. Aeby, "Community structure of hermatypic corals at French Frigate Shoals, Northwestern Hawaiian Islands: capacity for resistance and resilience to selective stressors," Pacific Science, vol. 60, no. 2, pp. 153-175, 2006.

[18] J. C. Kenyon, M. J. Dunlap, C. B. Wilkinson, K. N. Page, P. S. Vroom, and G. S. Aeby, "Community structure of hermatypic corals at Pearl and Hermes Atoll, Northwestern Hawaiian Islands: unique conservation challenges within the Hawaiian Archipelago," Atoll Research Bulletin, no. 549, pp. 1-23, 2007.

[19] J. C. Kenyon, C. B. Wilkinson, M. J. Dunlap, G. S. Aeby, and C. Kryss, "Community structure of hermatypic corals at Laysan Island and Lisianski Island/Neva Shoal in the Northwestern Hawaiian Islands: a new layer of scientific exploration," Atoll Research Bulletin, no. 550, pp. 1-28, 2007.

[20] J. C. Kenyon, M. J. Dunlap, and G. S. Aeby, "Community structure of hermatypic corals at Kure Atoll in the Northwestern Hawaiian Islands: stemming the shifting baseline," Atoll Research Bulletin, no. 559, pp. 1-25, 2008.

[21] J. C. Kenyon, C. B. Wilkinson, and G. S. Aeby, "Community structure of hermatypic corals at Maro Reef in the Northwestern Hawaiian Islands: a unique open atoll," Atoll Research Bulletin, no. 558, pp. 1-24, 2008.

[22] J. C. Kenyon, C. B. Wilkinson, and G. S. Aeby, "Community structure of hermatypic corals at Midway Atoll in the Northwestern Hawaiian Islands: a legacy of human disturbance," Atoll Research Bulletin, no. 581, pp. 1-24, 2010.
[23] D. Minton and M. Carnevale, "A preliminary survey of the marine and intertidal invertebrates of Kalaupapa National Historical Park (Moloka 'i, Hawai'i)," in Benthic Marine Community Vital Sign Monitoring Protocol_Pacific Island Network, E. Brown, D. Minton, R. Daniel et al., Eds., National Park Service, Oakland, Calif, USA, 2006, Natural Resource Report NPS/PWR/PACN/NRTR-2006/001.

[24] J. Beets, E. Brown, and A. Friedlander, "Inventory of marine vertebrate species and fish-habitat utilization patterns in coastal waters off four national parks in Hawai 'i," Pacific Cooperative Studies Unit Technical Report 168, Department of Botany, University of Hawai'i at Mānoa, Honolulu, Hawai'i, USA, 2010.

[25] P. S. Vroom and C. L. Braun, "Benthic composition of a healthy subtropical reef: baseline species-level cover, with an emphasis on algae, in the Northwestern Hawaiian Islands," PLoS ONE, vol. 5, no. 3, article e9733, 2010.

[26] G. J. Williams, J. E. Maragos, and S. K. Davy, "Characterization of the coral communities at palmyraatoll in the remote central pacific ocean," Atoll Research Bulletin, no. 557, pp. 1-32, 2008.

[27] J. E. Maragos and P. L. Jokiel, "Reef corals of Johnston Atoll: one of the world's most isolated reefs," Coral Reefs, vol. 4, no. 3, pp. 141-150, 1986.

[28] J. C. Kenyon, J. E. Maragos, and S. Cooper, "Characterization of coral communities at Rose Atoll, American Samoa," Atoll Research Bulletin. In press.

[29] S. S. Amesbury, D. Ginsburg, T. Rongo, L. Kirkendale, and J. Starmer, "War-in-the-Pacific National Historical Park marine biological survey," Tech. Rep., University of Guam, 1999.

[30] C. Wallace, Staghorn Corals of the World, A Revision of the Genus Acropora, Australian Commonwealth Scientific and Research Organization, Collingwood, Australia, 1999.

[31] J. E. N. Veron, New species described in Corals of the World, vol. 11 of Marine Science Monograph Series, Australian Institute, 2002.

[32] R. H. Randall, "An annotated checklist of hydrozoan and scleractinian corals collected from Guam and other Mariana Islands," Micronesica, vol. 35, pp. 121-137, 2003.

[33] J. E. N. Veron, Corals of the World, Australian Institute of Marine Science, Townsville, Australia, 2000.

[34] J. E. Hoffmeister, Some Corals from American Samoa and the Fiji Islands, vol. 343, Carnegie Institution of Washington, 1925.

[35] A. E. Lamberts, "An annotated check list of the corals of American Samoa," Atoll Research Bulletin, vol. 260-272, no. 264, 1983.

[36] J. E. Maragos, C. L. Hunter, and K. Z. Meier, "Reefs and corals observed during the 1991-92 American Samoa coastal resources inventory," Tech. Rep., American Samoa Department of Marine and Wildlife Resources, Pago Pago, American Samoa, USA, 1994.

[37] C. Mundy, "A quantitative survey of the corals of American Samoa," Tech. Rep. number, Department of Marine and Wildlife Resources, Pago Pago, American Samoa, USA, 1996.

[38] D. Fisk and C. Birkeland, "Status of coral communities on the volcanic islands of American Samoa, a re-survey of longterm monitoring sites," Tech. Rep., Department of Marine and Wildlife Resources, Pago Pago, American Samoa, USA, 2002.

[39] S. Coles, P. R. Reath, P. A. Skelton, V. Bonito, R. C. DeFelice, and L. Basch, "Introduced marine species in Pago Pago Harbor, Fagatele Bay and National Park Coast, American Samoa," Tech. Rep. 26, Bishop Museum, Honolulu, Hawai'i, USA, 2003. 
[40] E. DiDonato, C. Birkeland, and D. Fenner, "A preliminary list of coral species of the National Park of American Samoa," Tech. Rep. 155, Pacific Cooperative Studies Unit, 2006.

[41] E. R. Lovell and C. McLardy, "Annotated checklist of the CITES-listed corals of Fiji with reference to Vanuatu, Tonga, Samoa and American Samoa," Tech. Rep. 415, Joint Nature and Conservation Committee, 2008.

[42] National Park Service, "Corals of National Park of American Samoa," 2009, http://www.nps.gov/archive/npsa/ NPSAcorl/cornamsci.htm.

[43] IUCN Red List, 2010, http://www.iucnredlist.org/.

[44] C. C. Wallace, "New species and a new species group of the coral genus Acropora from Indo-Pacific locations," Invertebrate Taxonomy, vol. 8, pp. 961-988, 1994.

[45] "Fagatele Bay National Marine Sanctuary," 2010, http://fagatelebay.noaa.gov/html/management.html.

[46] National Park Service, "General Management Plan, National Park of American Samoa," 1997.

[47] B. W. Hoeksema, "Systematics and ecology of mushroom corals (Scleractinia: Fungiidae)," Zoologica Verehandelingen, vol. 254, p. 471, 1989.

[48] T. W. Vaughan, "Recent madreporaria of the Hawaiian Islands and Laysan," U.S. National Museum Bulletin, vol. 59, p. 427, 1907.

[49] IUCN Red List of Threatened Species, 2010, http://www .iucnredlist.org/apps/redlist/details/133574/0.

[50] T. Tomascik, A. J. Mah, A. Nontji, and M. K. Moosa, The Ecology of the Indonesian Seas, vol. 7, part 1, Periplus Editions, Hong Kong, 1997.

[51] J. E. Maragos, "Reef corals of Fanning Atoll," Pacific Science, vol. 28, no. 3, pp. 247-255, 1974.

[52] J. E. Maragos and P. L. Jokiel, "Reef corals of Canton Atoll. I. Zoogeography. An Environmental Survey of Canton Atoll Lagoon 1973," Final Report NUC TP 395, Naval Undersea Center, Hawai'i Laboratory, Kailua, Hawai'i, USA, 1976.

[53] G. Faure, "Annotated check list of corals in the Mascarene Archipelago, Indian Ocean,” Atoll Research Bulletin, vol. 203, pp. 1-26, 1977.

[54] C. R. C. Sheppard, "Coral species of the Indian Ocean and adjacent seas: a synonymized compilation and some regional distributional patterns," Atoll Research Bulletin, vol. 306-311, no. $307,1987$.

[55] J. E. Maragos, "Order Scleractinia," in Reef and Shore Fauna of Hawai ${ }^{\prime}$, D. M. Devaney and L. G. Eldredge, Eds., pp. 158-241, Bishop Museum Press, Honolulu, Hawai'i, USA, 1977.

[56] IUCN Red List of Threatened Species, 2010, http://www .iucnredlist.org/apps/redlist/details/133170/0.

[57] Z. H. Forsman, G. T. Conception, R. D. Haverkort, R. W. Shaw, J. E. Maragos, and R. J. Toonen, "Is Montipora dilatata an endangered coral species or an ecotype? Genes and skeletal microstructure lump seven Hawaiian species into four groups," Tech. Rep., NOAA Fisheries Pacific Islands Region Protected Resource Division, 2010. 

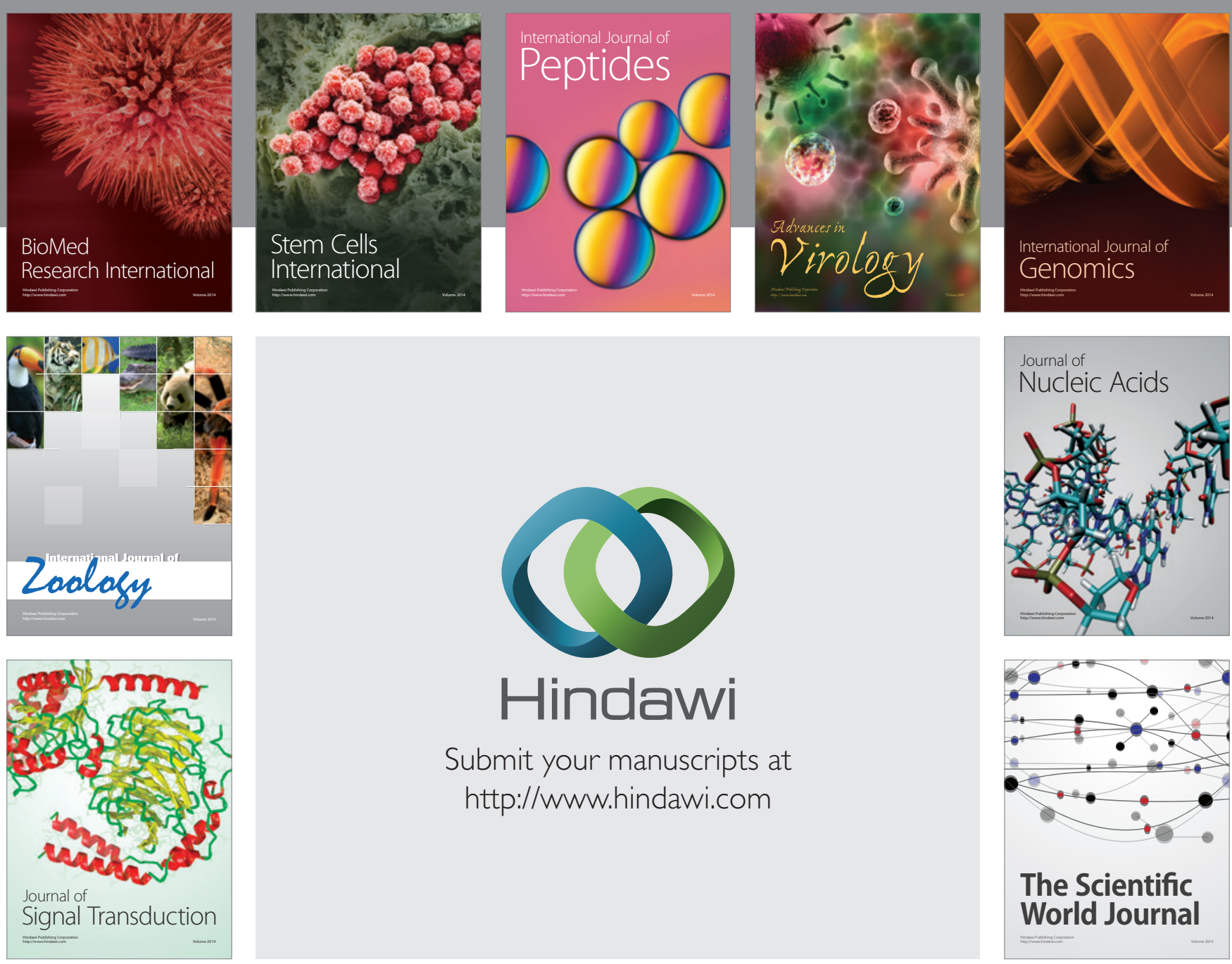

Submit your manuscripts at

http://www.hindawi.com
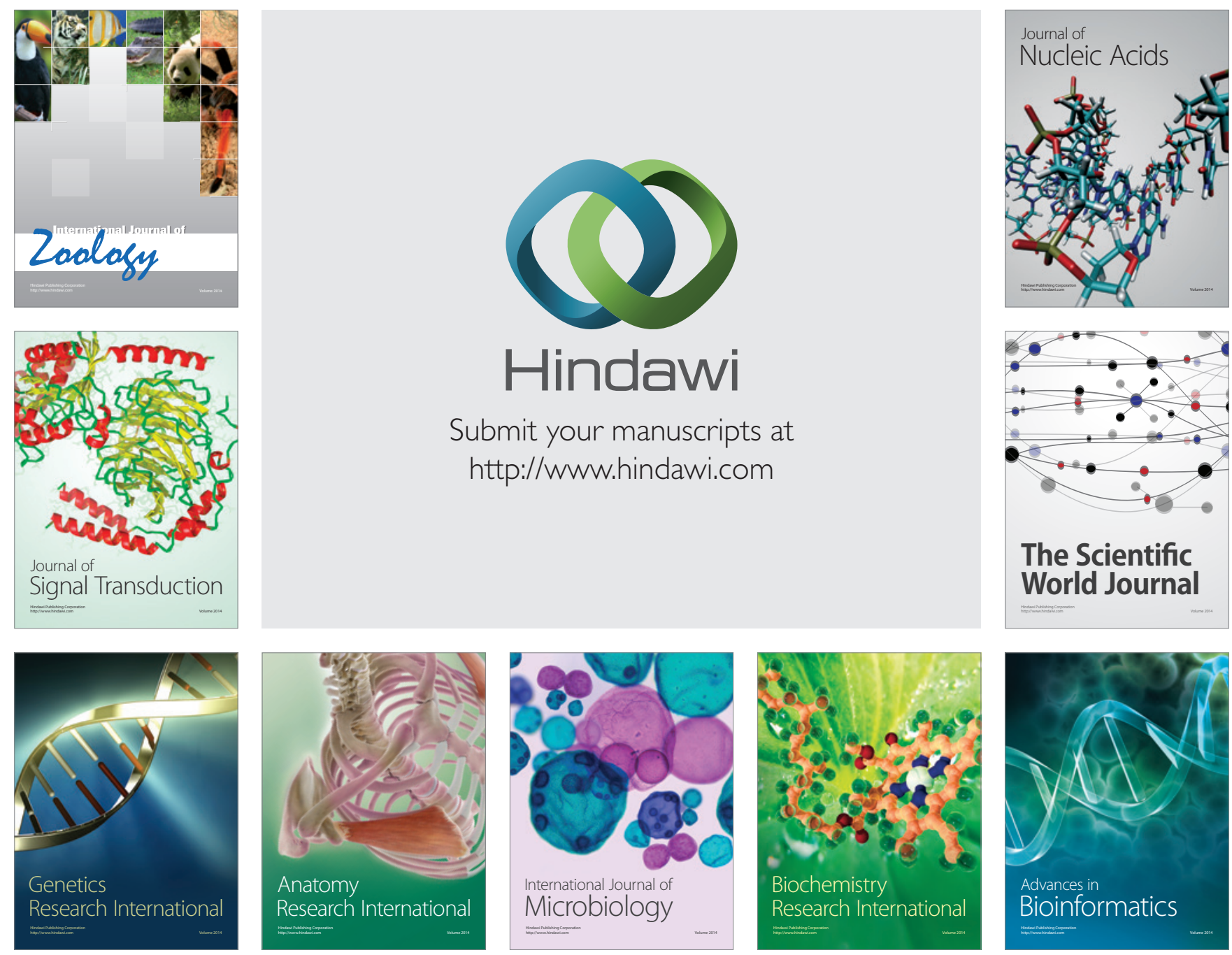

The Scientific World Journal
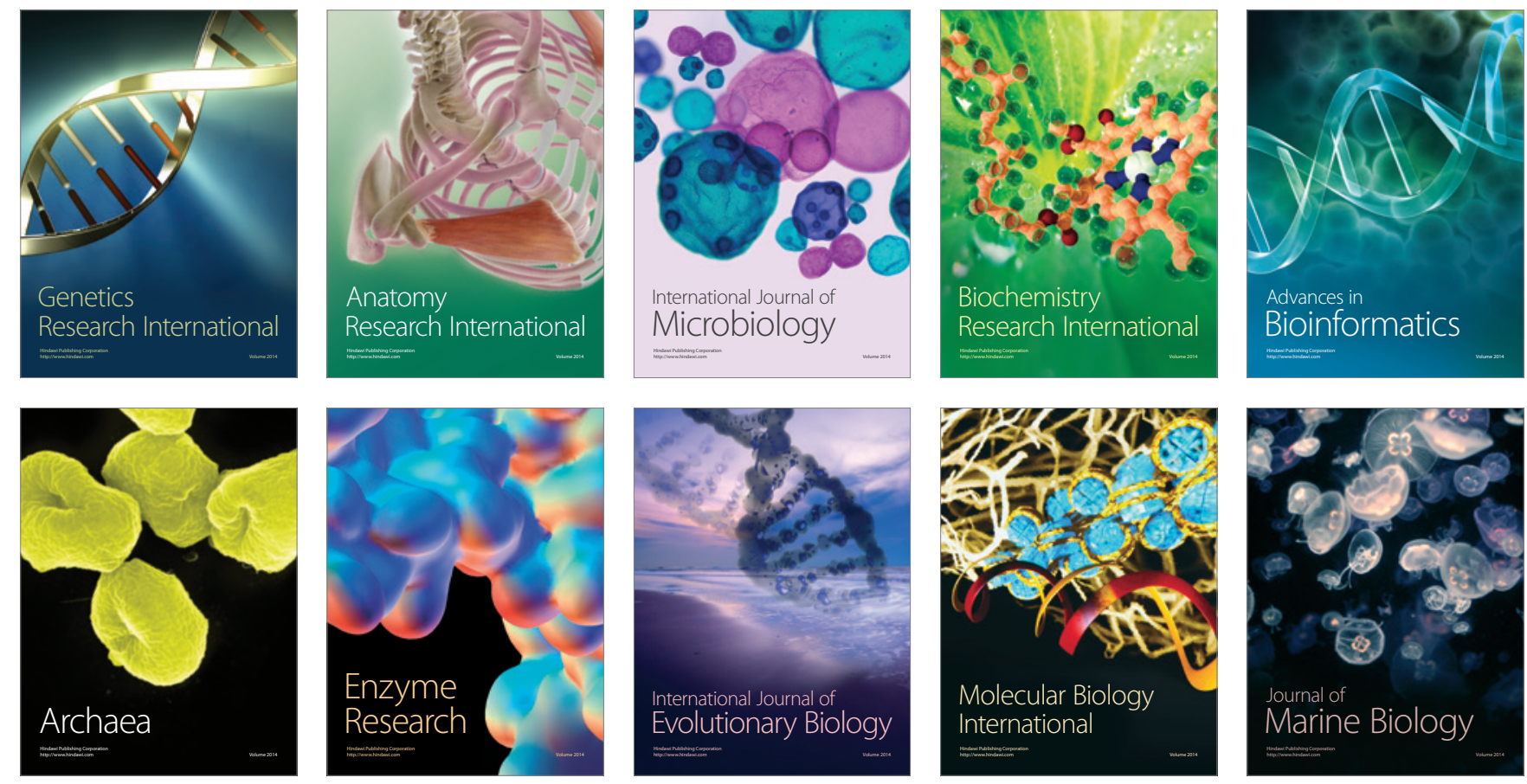